\title{
一次相転移のカイネティクス
}

\author{
防衛大学校材料物性工学教室 阿部 洋 \\ 筑波大学物理工学系 大嶋建一
}

\section{Hiroshi $\mathrm{ABE}$ and Ken-ichi OHSHIMA: Kinetics of the First-Order Phase Transition}

\begin{abstract}
A characteristic waiting time appears at fixed temperature above $T_{\mathrm{c}}$ or $M_{\mathrm{s}}$ for elements, alloys and polymers, where $T_{\mathrm{c}}$ is the usual first-order phase transition temperature and $M_{\mathrm{s}}$ is the normal martenstic phase transition temperature. This waiting time is called incubation time and related with the nucleation probability derived from a nucleation barrier. That is why nucleation process is regarded as thermal activated process at the non-equilibrium state. In particular, such a long incubation time of In-Tl alloys has a good agreement with experimental results by using Roitburd method. Furthermore, detailed and accurate experiments enable us to be aware that two dimensional growth occurs above $T_{\mathrm{p}}$, where peculiar temperature, $T_{\mathrm{p}}$, controls the time development of diffraction patterns and appears above $M_{\mathrm{s}}$ in this system.

In contrast to soft phonon model, incubation time is essential property of the first-order phase transition and the key to resolve nucleation and growth process.
\end{abstract}

\section{1. はじめに}

我々は自然現象を眺めていると,“結晶は生きている” と思わず声を出してしまう，その表情を端的に表してく れるのが相転移である. 古くにEhrenfest が相転移の定義 を行っており，現在もそれを用いて諸現象を分類してい る. 現在までに，一次および二次の相転移は見い出され ているが三次以上の相転移の報告例はない，その中で, 水の液体一固体転移, 気体一液体転移, 強誘電体の構造 相転移，形状記憶効果を示すマルテンサイト変態，液晶 の液体一液体転移や，金属一絶縁体転移（Mott 転移）な どの身近なもののほとんどの相転移が一次相転移と見な される.**最近注目を集めている $\mathrm{C}_{60}$ の回転配向転移や準 結晶一結晶転移もやはり一次相転移である。一方, $\mathrm{C}_{60}$ の 回転凍結転移は二次相転移となり, 同じ系でも一次相転 移と二次相転移が起きる場合がある。ここで，一次相転 移と二次相転移の違いは何に起因するのかという疑問が まず浮かぶだろう。現象論的な方法であるが秩序変数, $\phi$, で表される自由エネルギー， $G$, を導入すると，2つの種 類の相転移を簡単に比較, 分類することができる.ささら に，自然現象における自発的な多様性の発現である「対

\footnotetext{
*松原武生, 日本結晶学会誌 14, 201（1972）参照.
}

称性の破れ」も説明することができる，以下簡単のため 話を「変位型構造相転移」(原子の拡散を伴う秩序一無秩 序転移は含まない) に限る。

自由エネルギーに現れる一次／二次相転移の差とは， ある温度領域で母相と低温相の秩序変数の間に自由エネ ルギーのバリア， $\Delta$, が存在するかどうかである. 二次 相転移にはこのバリアがなく, 示強变数 (温度, 圧力, 電場, 磁場など）に対し連続的に相転移が進み, 体積変 化を伴わない．また，フォノン（振幅が小さく長距離に 及ぶゆらぎ）の凍結によって相転移機構を説明すること ができる。一方，一次相転移にはこのバリアが存在する ので，線型理論を適用することができない（図 1).さら に，体積変化を伴って相変化の不連続性を引き起こす。 つまり，一次相転移の初期状態においては局所的な非調 和なゆらぎから低温相の核生成が行われると考えられる。 この時, 相転移の不連続性から母相と低温相の間に界面 が形成されて二相共存状態になっている.ささらに，母相 とは関係ない低温相が出現するので, ミクロな相転移機 構の解明には非平衡状態の時間発展を追う必要性がある。 相転移という現象は新たな秩序がダイナミックに形成さ れることなので，時間軸上で秩序変化を動的に観察する のは当然の成り行きである.

カイネティクスに関する核生成・成長過程を定量的に 


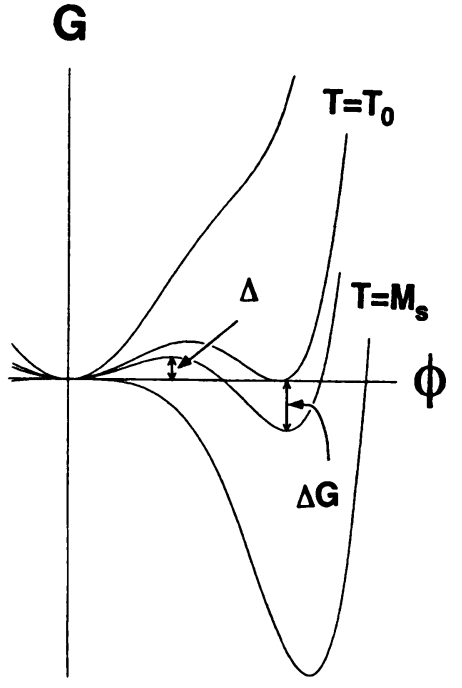

図 1 一次相転移の自由エネルギーの温度变化. $\Delta$ は核生 成バリアで, $\Delta G$ は母相と低温相の自由エネルギーの 差で，それぞれ特定の温度で, $\Delta\left(M_{\mathrm{s}}\right)=0, \Delta G$ $\left(T_{0}\right)=0$ となる.

記述する試みは古くから行われ，最初に, Kolmogorov1) やJohonson and Meh'2) によって独自に導入された。この モデルは，与えられている系の中で空間・時間的にラン ダムに核生成が起き，核生成速度が一定で，かつ，他の ドメインと出会うまでは等速・等方的に成長するという

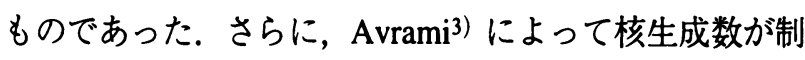
限された条件のモデルに拡張された。また，Cahnは，多 結晶を用いた時に核生成位置によって成長の時間依存性 が変わると示した.4)一方, Cahn and Hilliard の拡散方程 式5)は, 成長過程が指数関数的な時間発展をすると予測 した。ささに，古川は核生成・成長過程のスケーリング 則を定式化した .6)これらの理論の詳細は数多くの優れた 解説に譲る.7) -11) 一方, 計算機の発達により計算物理が ここ数年で大きな進歩を成し遂げた。例えば，拡散方程 式の応用例として結晶成長における表面の原子ステップ の計算機シミュレーションなどが積極的に行われている. さらに, 構造相転移のカイネティクスについては鈴木 ${ }^{12}$ が非調和性を取り入れて相転移が始まるまでに時間がか かることを計算機シミュレーションで示した。

しかし，一次相転移に現れる非線型性の上に非平衡状 態が絡むのでいまだに核生成問題が解かれていないのが 現状である。このように核生成過程は複雑な現象である が, 複雑であればあるほど個々の現象よりも現象の普遍 性を求めるのが世の常である。例えば，グリフィスによ って定式化されたスケーリング則 13) からウィルソンの くりこみ群理論 ${ }^{14)}$ への発展, マンデルブローのフラク タル幾何学の相転移のパターン形成への適用,15) ハーケ ンの「対称性のやぶれ」の立場からのパターン形成や自 己組織化現象を取り扱うことなどが挙げられる.16)一方,
相転移とは異なるが，流体に見られる自律的なゆらぎが 引き起こす多彩なパターン変化は，非平衡開放系の散逸 構造と呼ばれて一つの分野を確立している。このように 非平衡状態のゆらぎに関する研究は個別に発展してきた が，この流れは物理にとどまらず化学・生物・医学にも および新たに一大分野を切り開こうとしている．以下で はまず相転移におけるカイネティクスの研究の歴史的変 遷を述べ，次にはその中でも我々が特に興味を持ったマ ルテンサイト変態に関しての実験結果を詳細に報告する.

\section{2. 相転移におけるカイネティクスの研究の進歩}

一次相転移はすぐに相転移が終了してしまうので，実 験は理論に比べてかなり立ち後れていた，そのため，位 置敏感比例計数管 (PSPC), 半導体検出器 (SSD), イメ ージングプレートなどの検出器を用いて一挙に回折パタ ーンを測定する手法や，放射光などの強力な X 線源を用 いる工夫がとられた，まず，実験で行われた手法は，前 者のPSPCを用いて, さらに, 突然, 相転移の起こる環 境に変化させて平衡状態になるまでの観察であった，例 えば, $\mathrm{NaNO}_{2}{ }^{17)}$ やSC $\left(\mathrm{NH}_{2}\right)_{2}{ }^{18)}$ の不整合相の転移点直 上で電場を加えて強制的に強誘電相に相転移させた。 ミ リ秒のオーダの時間で相転移が終わるため通常の $\mathrm{X}$ 線発 生装置を用いると, 測定を数千回繰り返して衛星反射強 度を積算して $I(q, t)$ を求める必要性があった。ささら に, 緩和時間で時間をスケールすると電場の強さにかか わらずユニヴァーサル曲線になることが示された。 また， 秩序一無秩序相転移については転移点 $T_{\mathrm{c}}$ の上から $T_{\mathrm{c}}$ 以下 の温度 Tに急冷（温度ジャンプ）後, 温度を一定に保ち, $\mathrm{Cu}_{3} \mathrm{Au}$ の秩序化過程の測定 ${ }^{19)}$, 20) が行われた. 秩序 - 無 秩序転移は比較的遅く相転移が進むのでインキュベーシ ヨン・タイム（潜伏時間）が観測された。インキュベー ション・タイムとは温度一定の条件で相転移が始まるま での待ち時間のことである，時間とともに低温相からの 超格子反射の半值幅の $\Gamma(t ; \Delta T)$ が小さくなり, 徐々に秩 序相のドメインが成長していくのがわかる。ここで, $\Delta T=T_{\mathrm{c}}-T$ となる. また, ある時間 $\tau_{\mathrm{c}}$ からの半值幅の 時間変化は次式で表される.

$$
T(t ; \Delta T) \propto t^{-1 / 2} \quad\left(t>\tau_{\mathrm{c}}(\Delta T)\right)
$$

さらに, $t=\tau_{\mathrm{c}}$ のときの半值幅を $\Gamma_{\mathrm{c}}$ として, $\tau_{\mathrm{c}}$ と $\Gamma_{\mathrm{c}}$ で スケールすると $\Delta T$ に依存しないユニヴァーサル曲線が 得られる。

次に, 高圧で $\mathrm{NaCl}$ 構造から $\mathrm{CsCl}$ 構造に相転移する $\mathrm{RbI}$ のカイネティクスが中性子回折実験を利用して行われた。 温度 ·圧力・時間の系統的な測定 21) が行われて, Kolmogorovモデル 22) を用いて圧力に対する臨界半径と 核生成バリアが求められた。ここで, 臨界半径とは, 高 圧相の核生成に必要な大きさである。つまり，臨界半径 
を越えると高圧相の核生成が起こり核成長が始まるが, 臨界半径以下のものは消滅する．Kolmogorov モデルは， インキュベーション・タイムの間の局所ゆらぎの大きさ と振幅を考慮していないので古典的な核生成・成長モデ ルと見なされる。一方，逆転移にもインキュベーショ ン・タイムが観測された。 また，以前に”相転移の時間 変化の研究”という内容が本誌で報告されている.23)，24) これらの実験では，一つの成長曲線にスケールされるこ とによるスケーリング則の検証か研究の中心だった。

さらに，実験技術の進歩により広い逆格子空間に分布 する弱い散乱強度の X 線散漫散乱の時間分割実験が可能 になった。この先駆的な仕事は複雑な相転移をする $\mathrm{Ag}$ $\mathrm{Zn}$ 合金を用いて高輝度の放射光 $\mathrm{X}$ 線源と高感度のイメー ジングプレートを組み合わせて行われた. ${ }^{25)}$ 高温でbcc 構造の Ag-Zn 合金を転移点 (530K) 以下に急冷すると準 安定の $\mathrm{CsCl}$ 構造に相転移をする.ささらに, $330 \mathrm{~K}$ 以上に 加熱すると安定相の六方晶系構造が現れる. 特に, 準安 定相から安定相への転移において, 散漫散乱強度分布の 顕著な時間変化は見られず，原子の部分的な拡散と（111） 面のシフトが局所的に整然と起きていることが明らかに なった，今後，このような複雑な相転移をするものでい まだに相転移機構のわからないものでも時間発展実験に よって解明される可能性がある.

\section{3. 最近のカイネティクスの研究}

\section{1 $\mathrm{Fe}-\mathrm{Ni}$ 基合金}

マルテンサイト変態は, 原子の拡散を伴わず，低温相 が母相と一定の方位関係を保ちながら連携的に変態が進 む典型的な一次相転移である. 特に形状記憶効果（熱弾 性型マルテンサイト変態に限る）を示すことから古くか ら興味が持たれて, 工業的な応用とともに構造相転移に 関する基礎研究が行われてきた. カイネティクスの見地 からマルテンサイト変態は, 等温マルテンサイト变態と 非等温マルテンサイト変態に分類される，前者は，変態 量が図2のように温度と時間に依存するのに対し, 後者 は温度だけに依存する。ここで注目すべき点は, 等温マ ルテンサイトは時間と温度の関数で表されて, 温度一定 の条件下でインキュベーション・タイムが観測されるこ とである. 掛下らは, 現象論的なモデルを導入して非等 温・等温マルテンサイト変態を両カイネテイクスを統一 的に解粕している。.26) 例えば，等温マルテンサイトの Fe$\mathrm{Ni}-\mathrm{Mn}^{27)}$ や Fe-Ni-Cr ${ }^{28)}$ に強磁場を印加すると非等温マル テンサイト変態になったり, 非等温マルテンサイトの Fe$31.5 \mathrm{Ni}-0.5 \mathrm{Mn}$ (at \% ) 29) に静水圧をかけると等温マルテ ンサイトになる。また, $\mathrm{Fe}-31.7 \mathrm{Ni}^{30)}, \mathrm{Cu}-28.6 \mathrm{Al}-3.2 \mathrm{Ni}$ (at \%) 31) などの時間に依存しないはずの非等温マルテン サイトにも転移点以上でインキュベーション・タイムが 観測された。これらの実験結果は，核生成過程を熱活性
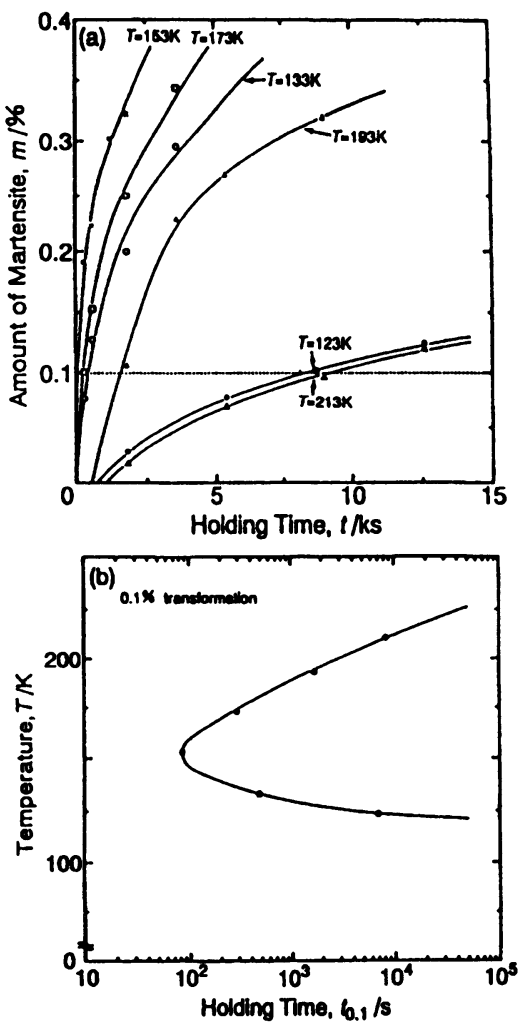

図2 $\mathrm{Fe}-24.9 \mathrm{Ni}-3.9 \mathrm{Mn}$ 合金の（a）等温マルテンサイトの 生成量と保持時間，（b）各温度での $0.1 \%$ の生成量の インキュベーション・タイム.27)

化過程と見なした確率論的なモデルで説明されている.32) このモデル計算から $1.5 \mathrm{~nm}$ 立方程度の臨界サイズが求め られた．相転移の起こる環境への突然の変化の実験では ないので，インキュベーション・タイム自体に意味があ り，核生成過程が遷移過程であることを実証した。また， 強磁性, 反強磁性, スピングラスなどの磁性の立場から カイネティクスを議論している点も興味深い.

\section{2 稀土類}

稀土類金属は複雑な磁気転移を示すことはよく知られ ている，例えば，Dyは，らせん一強磁性転移を示し，Er はネール点 $\left(T_{\mathrm{N}}=84 \mathrm{~K}\right)$ 以下でスピンがサイクロイド構造 になり，19Kで円錐らせん配列をとる。稀土類を用いた カイネティクスの研究は, Dy4 \% Y 合金 ${ }^{33)}$ やDy34) で行 われた。しかしながら，10Kに下げてもスピンのらせん 配列と強磁性の二相共存状態で安定な単相にはならなか ったささらに，Dy4\% Y 合金は，狭い温度範囲でしかカ イネティクスが見られなかったので，安定な単相に相転 移をするErを用いて系統的なカイネティクスの実験が行 われた ${ }^{35)} \mathrm{Er}$ の構造は六方晶系で結晶構造の変化はない が $19 \mathrm{~K}$ でC 軸の格子定数が Dy に比べて2 倍程度不連続 に変化する．この実験では，各温度 $\left(\Delta T=\left|T-T_{\mathrm{c}}\right|\right)$ でPSPC を用いて逆格子空間の二次元測定してブラッグ 反射の積分強度の時間変化を求めた。ここで， $T_{\mathrm{c}}$ は，転 
移点と逆転移の中間の温度で $\mathrm{Er}$ では $18.5 \mathrm{~K}$ と評価された (図 1 の $T_{0}$ に相当する)。なお，ヒステリシスは $2 \mathrm{~K}$ と小 さいが温度は $0.05 \mathrm{~K}$ 以内で制御されている。詳細な実験 結果からインキュベーション・タイムが 19Kに近づくに つれて発散する。これは，非等温マルテンサイトに見ら れる現象と同じ振る舞いで, 逆転移においてもインキュ ベーション・タイムが同様に観測された。 さらに, 成長 曲線は, 強誘電体の $\mathrm{BaTiO}_{3}$ の常誘電体 (立方晶) から強 誘電体 (正方晶) のカイネティクスで用いられたChandra の核生成・成長モデルで説明することができた，という のは, 稀土類の磁気モーメントが一軸上の格子変位と強 く結びついているためである.

\section{3 高分子}

次に，金属，合金とはまったく異なる高分子の分野で もインキュベーション・タイムが観測されている. 高分 子における核生成問題とは, ランダムに絡み合った高分 子鎖がどのような秩序形成をするのかという点である. 最近, 今井らは, 結晶化速度の遅いポリエチレンテレフ タレート（PET）を用いて非晶質状態からの核生成過程 の初期段階の動的な構造形成を明らかにした．36－38）時間 分割小角 $\mathrm{X}$ 線散乱実験により結晶化が始まる前のインキ ユベーション・タイムの間に, 何らかの規則的な長距離 秩序の形成・成長が見られたと報告した。 さらに，イン キュベーション・タイム間の秩序形成が前期過程と後期 過程の二段階に分けられることを見出した（図3）。特 に, 前期過程は現象論的な線型理論範囲内で記述するこ とができ二相分離過程のカイネテイクスと非常によく似 ている. 一方, 後期過程は 1 節で述べた非線型な古川の モデルとよく一致する.つまり, ゆらぎの振幅が一定に なり，その反面，ゆらぎの大きさが大きくなっていくこ とに対応する. その結果, 後期過程ではゆらぎの大きさ だけでスケールすることができる.

また，この他にコロイド結晶, ガラス転移やゾルーゲ ル転移など多くのカイネティクスに関する研究が行われ ている.

\section{4. 我々の研究：金属ナトリウムと In-TI 合金}

リチウムとナトリウムは, bcc 構造から 9R 構造にマル テンサイト変態をする．さらに，カイネティクスの見地 からは，非等温マルテンサイトと見なされる.39) アルカ リ金属は，合金に必ず現れる組成ゆらぎが無視できるの で前駆現象という立場から中性子非弾性散乱実験が精力 的に行われてきた.40)，41) しかし，bcc-9R 相転移で予想 されていた $\mathrm{TA}_{2}[\zeta \zeta \bar{\zeta} 0]$ フォノンモードの $\zeta=1 / 3$ のソフト 化は見られなかった．しかし，リチウム42)では数分，ナ トリゥム43) では約 2 時間のインキュベーション・タイム が観測された．図4がナトリウムの母相の $110_{\mathrm{bcc}}$ ブラッ グ反射の半値幅の時間変化である. 温度を $38 \mathrm{~K}$ (転移点

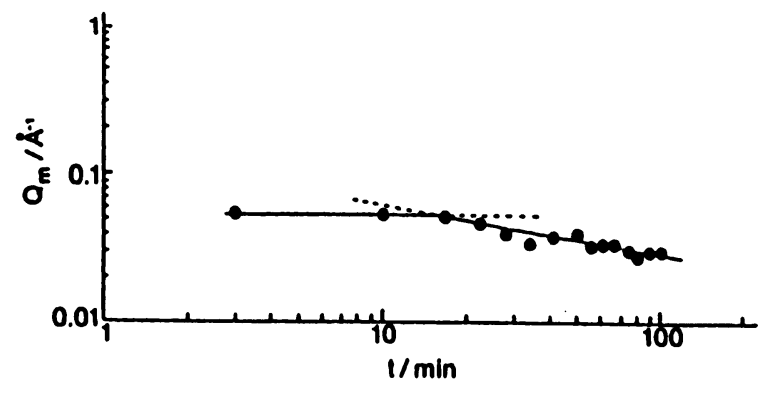

図3高分子のインキュベーション・タイムの間の散乱ピ 一ク位置の時間変化.36)

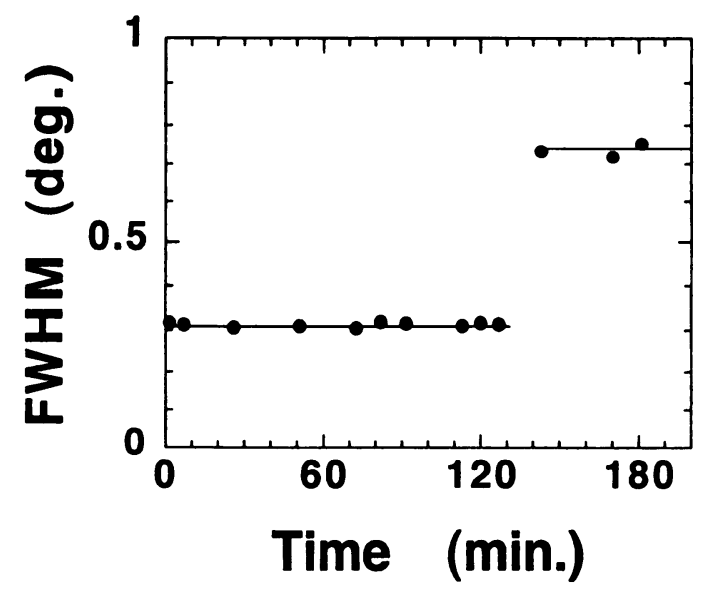

図4 ナトリウムの $110_{\mathrm{bcc}}$ ブラッグ反射の時間変化.

は35 K) にして一定に保つと, 約 2 時間のインキュベー ション・タイムの後にブラッグ反射の半值幅が増大した. このときの半值幅の不連続な増大は, 低温相の発生によ り母相が歪んだ結果である。 また，核生成が起こると同 時に核成長も数分の内に終了することがわかる.ささらに, 相転移終了後に $110_{\mathrm{bcc}}$ ブラッグ反射回りの 2 次元測定を 行うと, 2 つの低温相のバリアントの $009_{9 \mathrm{R}}$ ブラッグ反射 と熱散漫散乱（TDS：Thermal Diffuse Scattering）およ びTDS とは異なる散漫散乱が観測された（図5（b)）。散 漫散乱の温度変化を考慮すると, 母相の中に低温相のク ラスターが形成されることによって母相が歪み，その静 的な歪みからの Huang 散漫散乱 (HDS : Huang Diffuse Scattering) と考えられる. しかし, 逆転移後 $(T=70 \mathrm{~K})$ で完全に相転移前の散乱分布に戻らない.つまり, バー ス卜的な核成長が塑性変形（非可逆的な転位・欠陥）を 引き起こし，逆転移後も存在している．そこで，この塑 性変形による歪みからの散漫散乱を EDS (Extra Diffuse Scattering）と呼ぶことにする，さらに，同じ試料をもう 一度相転移させると $10 \mathrm{~K}$ で 14 分のインキュベーション． タイムとゆっくりとした低温相の成長過程か観測された。 まず転移点の低下は, 通常のバリアの上に塑性変形の歪 
[k]
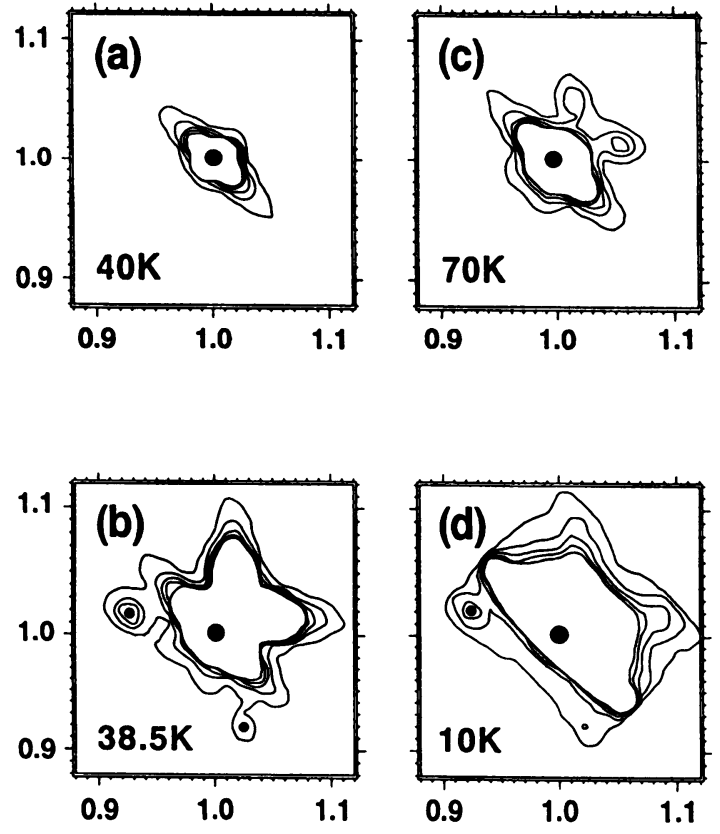

図 5 各温度での $110_{\mathrm{bcc}}$ ブラッグ反射まわりの強度分布. (a) 相転移前, (b) 相転移後, (c) 逆転移後, (d) 二 回目の相転移後.

みエネルギーが加算されるためである．また，短いイン キュベーション・タイムと遅い成長過程は, 塑性変形が ピンニング的な役割をしてバースト的な自由な核成長を 抑えていると考えられる. 2 回目の相転移後の強度分布 （図5 (d)）からも，より多くの塑性変形が発生している がわかる。これらをふまえると強度式は,

$$
I=I^{\mathrm{Bragg}}+I^{\mathrm{TDS}}+I^{\mathrm{EDS}}+I^{\mathrm{HDS}}+\left(I^{\mathrm{EDS}} * I^{\mathrm{HDS}}\right)
$$

となる (*はコンボリューション). 最初の相転移で は，転位・陥による歪みと低温相のクラスターのまわ りの母相の歪みの干渉が弱く（IEDS*IHDS）を無視できる が，2回目の相転移のときにはこの項を無視することは できない.そこで, コンボルーションの項を考えないで Huang 散漫散乱理論44）に基づいて計算をすると，実験結 果をよく再現している（図6). ゆえに，インキュベーシ ヨン・タイムは良質な結晶にしか現れないということが わかる.この原因に転位や欠陥が多いとランダムに発生 するはずの核がそこに優先的にトラップされることが考 えられる.

よく知られている通りに, アルカリ金属は, 非常に柔 らかいので内部応力の影響を受け易く，不可逆的な塑性 変形が発生する，そのため，逆転移させても結晶性が完 全に元に戻らない. その上, 外からの応力にも敏感で, 固定の仕方によって転移点が $20 \mathrm{~K} ３ 8 \mathrm{~K}$ と変動する（化 学的に反応しやすく接着剤で固定することができない). 結局，実験のたびに新しい結晶を使用しなければならな

\section{[ $0 \mathrm{ko}]$}

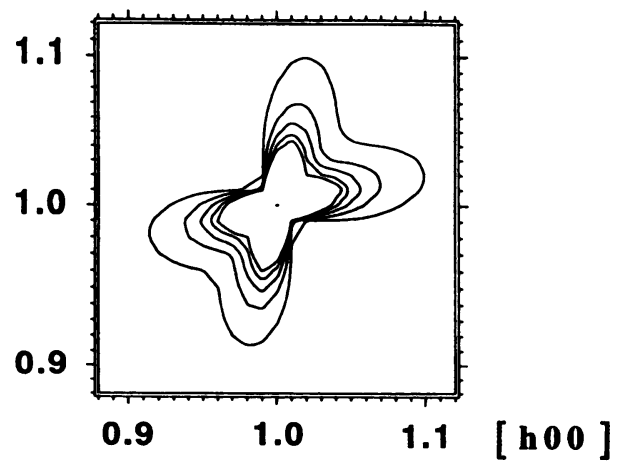

図6 モンテカルロ法で計算された Huang 散漫散乱強度分 布.

いのでサンプル依存性が無視できなくなり，系統的なカ イネティクスの研究には適さない. 一方, 熱弾性型の In$\mathrm{T} 1$ 合金は相転移前後の体積変化がわずかで逆転移後も完 全に元の結晶性に戻るため, 同じサンプルを用いて何回 でも繰り返して実験ができる。これらの理由で，我々は 系統的なカイネティクスの研究を In-Tl 合金に対して行っ た。なお，詳細な中性子非弾性散乱測定が行われている がフォノンのソフト化は報告されていない.45)

試料として In-23at \% Tl 合金の単結晶を用いて X 線時 間分割実験が行われた.46) 波長は, Mo の K $\alpha(\lambda=$ $0.07107 \mathrm{~nm})$ がHOPG (Highly oriented pyrolytic graphite) モノクロメーターで選択された。 各温度サイクルの前に 室温で 12 時間アニールした。 また, 精密温度制御装置に よって, $265 \mathrm{~K}$ から $1 \mathrm{~K} / \mathrm{min}$ の冷却速度でオーバーシュ ートせずにインキュベーション・タイムの測定温度に到 達することができる.ここでの $265 \mathrm{~K}$ は逆転移点 $\left(A_{\mathrm{s}}=\right.$ $261.8 \mathrm{~K})$ よりも高い温度である. 温度の安定性は土 0.05 $\mathrm{K}$ であり，0.5 K 間隔のインキュベーション・タイムの測 定が十分可能になった．図7（b）を見ると，ある温度以 上ではX 線回折パターンの時間変化に再現性（必ず同じ 角度に2つの低温相のピークが出現し, 何回実験を繰り 返してもその位置は変化しない）があるのに対し，ある 温度以下では図7（a）のように再現性もなく，その上, 複雑な回折パターンの時間変化をすることがわかった. この原因に In-Tl 合金のX 線の侵入長が $20.3 \mu \mathrm{m}$ となり表 面効果が考えられたので，中性子回折実験を行った（波 長 $\lambda=0.235 \mathrm{~nm}$ で侵入長が $1.36 \mathrm{~mm}$ ). 中性子回折パターン にも，ある温度を境に顕著に回折パターンの時間変化が 現れた（図7 (c)，(d)).したがって，バルクでもこの ように異なる核生成・成長が実現しているので, 境目と なる温度を特性温度 $T_{\mathrm{p}}$ と定義する． $T_{\mathrm{p}}$ 以下の回折パター ンが複雑な時間変化をするので途中でどれが母相でどれ が低温相になるのかがわからなくなる. その結果, $T_{\mathrm{p}}$ 以 下の成長曲線を求めるのは不可能になる。一方, In-Tl 合 


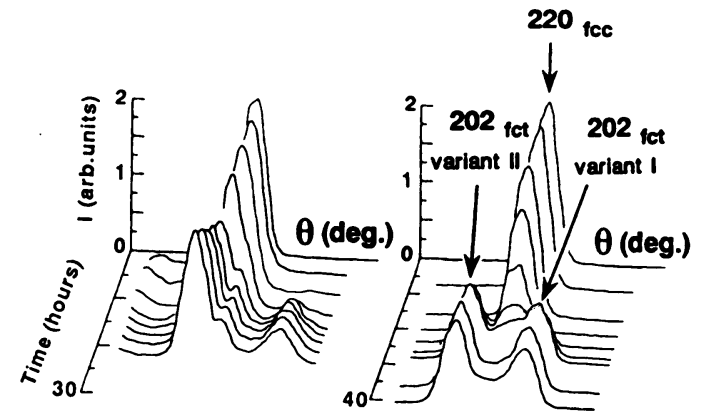

(a) 253.0K

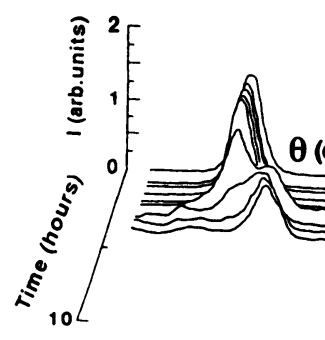

(c) $245.0 \mathrm{~K}$ (b) $255.0 \mathrm{~K}$

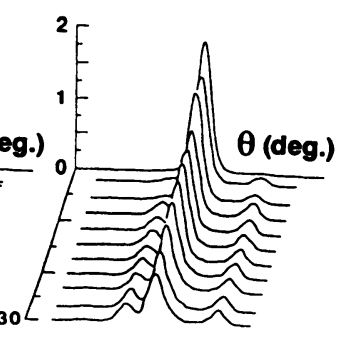

(d) $254.0 \mathrm{~K}$

图7 HOPG モノクロメーターを用いたときの X 線回折パ 夕ーンの時間変化 (a) $T<T_{\mathrm{p}}$, (b) $T>T_{\mathrm{p}}$. 中性子回 折パターンの時間変化 (c) $T<T_{\mathrm{p}},(\mathrm{d}) T>T_{\mathrm{p}}$.

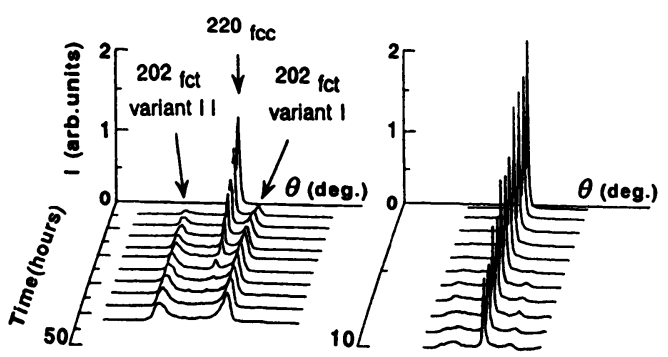

(a) $255.0 \mathrm{~K}$

(b) $255.25 \mathrm{~K}$

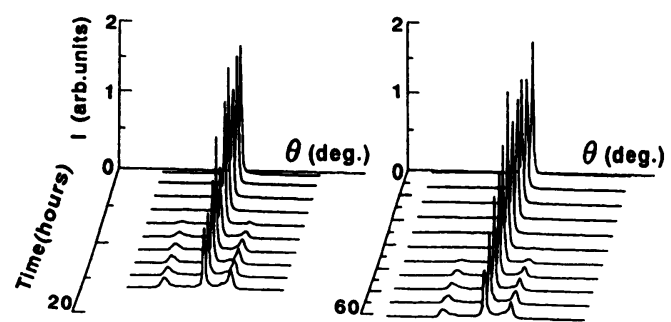

(c) $256.0 \mathrm{~K}$

(d) $256.7 \mathrm{~K}$

図8 Si モノクロメーターを用いたときの X 線回折パター ンの時間変化.

金の相転移前後の体積変化が非常に小さいので母相のブ ラッグ反射の近くに低温相のブラッグ反射が現れる。イ ンキュベーション・タイムおよび成長曲線を正確に求め るためにそれぞれのピークの分離ができる高分解能な光 学系を使わなければならない. Moの $\mathrm{K} \alpha_{1}$ を $\mathrm{Si}$ (311) の モノクロメーターで選択した高分解能の光学系では, $220_{\mathrm{fcc}}$ ブラッグ反射と $2 つ$ づリアントの $202_{\mathrm{fct}}$ ブラッグ

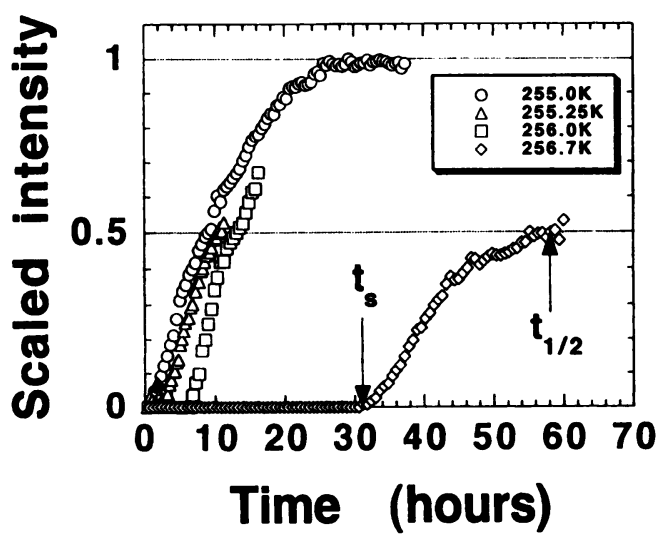

図9 各温度の成長曲線. $t \rightarrow \infty$ で積分強度が 1 になるよう に規格化してある。

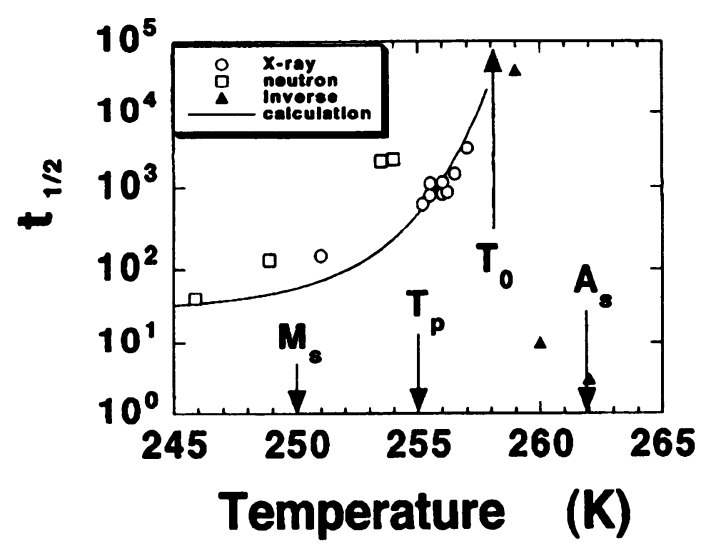

図 $10 \mathrm{t}_{1 / 2}$ 曲線. $T_{0}$ に近づくにつれてインキュベーショ ン・タイムが発散する.

反射を完全に分離することができた（図8).このときの 母相の $220_{\mathrm{fcc}}$ ブラッグ反射の半值幅は $2.0^{\prime}$ で, 光学系の 分解能関数は $30 "$ であった. なお, 各温度で母相のピー クか残っているのは, 非常にインキュベーション・タイ ムが長いので途中で測定を打ち切っているためである.

母相の積分強度が出発点のそれと比較して半分に減少 すると, 低温相の積分強度が完全に低温相になった時の 強度の半分に増大する。 そこで各温度の成長曲線の強度 を（3）式のようにスケールすると図9のようになる。

$$
X(t)=\{I(t)-I(0)\} /\{I(\infty)-I(0)\}
$$

低温相の成長曲線 $X(t)$ は, 設定温度を高くするにつ れてインキュベーション・タイムが長くなるのがわかる. さらに $X(t)=1 / 2$ になるような時間を $t_{1 / 2}$ とすると, 設定 温度と $t_{1 / 2}$ の関係は図 10 のようになる. $t_{1 / 2}$ は, $T_{0}$ に近づ くにつれて発散して, かつ, 逆転移にも $T_{0}$ を中心に非対 称であるが, 同じようなインキュベーション・タイムが 見られた。ここで $T_{0}$ は， $\Delta G\left(T_{0}\right)=0$ と母相と低温相の 自由エネルギーの差が0になる温度 (図 1参照) で, 図 


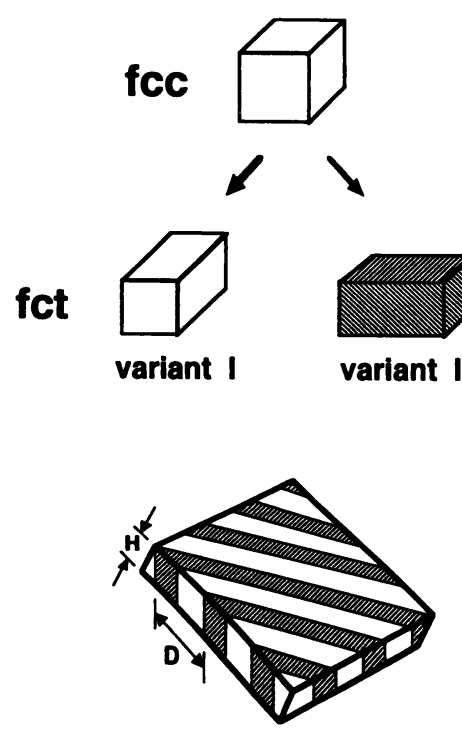

図11 Roitburdによる二次元の多層ドメイン・マルテンサ イト.47) それぞれ，バリアント1からなるドメイン 1 とバリアント 2 からなるドメイン 2 が周期的に並 んでいる.

10 から $T_{0}=258.0 \mathrm{~K}$ とした.

Roitburd は, 転移点 $\left(\mathbf{M}_{\mathrm{s}}\right)$ 以上で多層ドメイン・マル テンサイト（不均一マルテンサイト）の核生成バリアの 方が単層ドメイン・マルテンサイト（均一マルテンサイ 卜）よりも小さくなると計算した、47)これは，強磁性体 の磁区と同じ考えで弾性論的に適用されている．界面で は，2つのバリアントがなめらかに接続している。この なめらかに接続している部分だけが低温相の構造とは異 なる．まず， $\mathrm{L} \times \mathrm{L} \times \mathrm{H}$ の板状単層マルテンサイトを考 えると自由エネルギーは，

$$
\mathrm{G}=\{-\Delta \mathrm{g}+\mathrm{e}(\mathrm{n})\} \mathrm{HL}^{2}+\mathrm{e}_{\mathrm{L}} \mathrm{H}^{2} \mathrm{~L}+\Gamma^{2}(\mathrm{H} \ll \mathrm{L})
$$

と表せる. $\Delta g$ は，母相と低温相の自由密度エネルギーの 差である．「は， $\mathrm{L} \times \mathrm{L}$ 面の単位面積当たりの界面エネ ルギーで，他方， $\mathrm{e}_{\mathrm{L}}$ は $\mathrm{H} \times \mathrm{L}$ 面の端の弾性場の界面エネ ルギーである。一方，多層ドメイン・マルテンサイトの 場合は，図11のよjにバリアント1 からなるドメイン 1 とバリアント 2 からなるドメイン 2 が交互に 2 次元的に 並んで周期ドメイン構造を形成している（現在，3次元 多層ドメイン・マルテンサイトは解析的に解けない)。 ま ず，ドメイン 2 の体積比を $\alpha$ として，ドメイン 1 とドメ イン 2 の 1 組の厚さを $D$ とすると,

$$
\begin{aligned}
G= & \{-\Delta g+e(\alpha)\} H L^{2}+e_{L}(\alpha) H^{2} L+\Gamma L^{2} \\
& +\left\{2 \gamma H / D+2 \alpha^{2}(1-\alpha)^{2} e_{\mathrm{s}} D\right\} L^{2}
\end{aligned}
$$

となり，(4) 式に（5）式の後ろの2 項が加わっている. ここで, $\gamma$ はドメイン 1 とドメイン 2 の界面エネルギーで 厚さDに反比例する．また， $\mathrm{e}_{\mathrm{s}}$ はミクロな応力による弾 (a)

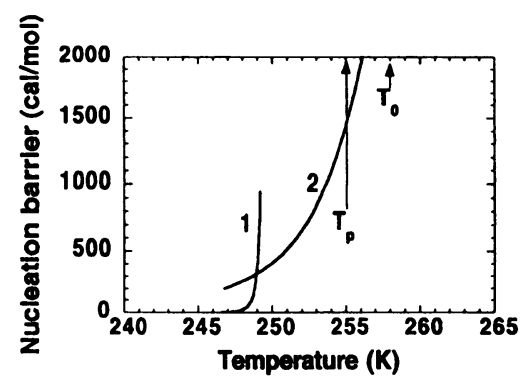

(b)

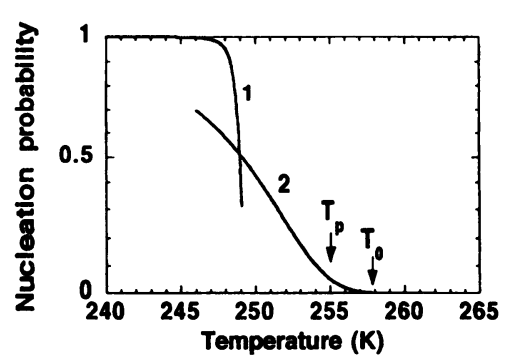

図 12 （a）Roitburd の方法で計算された核生成バリア．(b) 核生成確率. 曲線 1 は単層ドメイン・マルテンサイ トで曲線 2 は多層ドメイン・マルテンサイト。

性エネルギーである．実際に，In-23at. \% Tl の場合につ いて計算すると，図12（a）のようにそれぞれ単層，多 層ドメイン・マルテンサイトの核生成バリアが求められ る。温度が $T_{0} に$ 近づくにつれて核生成バリアは発散す る.さらに核生成バリアを $\Delta(T)$ として核生成過程がボ ルッマン因子で記述される熱活性化過程と見なすならば, 核生成確率 $p$ は

$$
p \propto \exp \left\{-\Delta(T) / k_{\mathrm{B}} T\right\}, t \propto 1 / p
$$

となる.23) 式（6）で求められた核生成確率は，図12（b) のように $T_{0}$ 以上で 0 になる. 一方, $T_{\mathrm{p}}<T<T_{0}$ の温度範 囲ではわずかながらも核生成確率があり，インキュベー ション・タイムを計算すると図10の実線となる。

\section{5. 新しい考えに基づくカイネティクスの解釈}

$\mathrm{In}-\mathrm{T} 1$ 合金で，なぜ $T_{\mathrm{p}}$ を境に回折パターンの時間発展が 異なるのだろうか?この疑問に答えるために以下のよう な仮定 $1 ， 2$ を導入すると始めて実験結果をうまく説明す ることができる.

仮定 1. $T_{\mathrm{p}}$ 以上の温度範囲では変態駆動力が核生成確 率に比例して小さくなり, 発生した核は自分自身で大き くなることができない. その結果, 表面のポテンシャル の影響を受けやすく表面から核生成・成長がおこり，図 13 のような二次元的な成長が起こる.

仮定 2. $T_{\mathrm{p}}$ 以下では結晶内部から核生成がおこり, 通 常のドメイン壁が動く古典的な核生成・成長が起きてい る.

仮定 1 から， $T_{\mathrm{p}}$ 以上での回折パターンの時間変化に再 


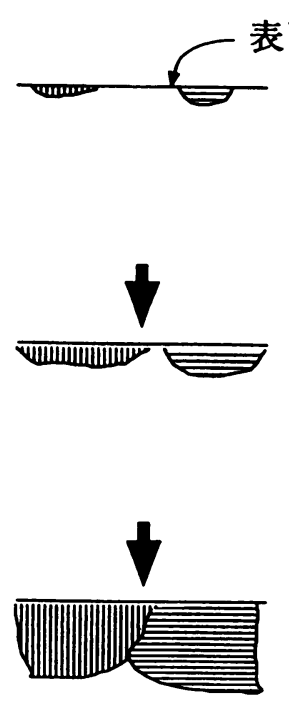

(a) $T>T_{p}$

(b) $\mathrm{T}<\mathrm{T}_{\mathrm{p}}$

現性は，核生成・成長の空間の制約に起因する．実際に， 相転移終了後の低温相のブラッグ反射の測定によって二 次元的な成長が裏付けられた。例えば, $T_{\mathrm{p}}$ 以下で $3 \supset の$ バリアントのブラッグ反射が観測されたのに対し， $T_{\mathrm{p}}$ 以 上では 4 軸回折計を用いて逆格子空間を 3 次元的に測定 しても2つのバリアントのブラッグ反射しか見られなか った，さらにここの仮定はもう一つの疑問のであった” 中性子散乱実験で観測された $t_{1 / 2}$ の方が $\mathrm{X}$ 線の実験に比 べて長い”にも明確な答えを与えてくれる．中性子回折 実験の方が散乱に寄与する体積が大きくなるので表面か ら成長することを考慮すると, 成長量が散乱体積の半分 になるまでの時間 $t_{1 / 2}$ は中性子回折実験の方が長くなる ことが受け入れられる.

これに対し, 通常の成長過程と比べると一層明らかに なる. 古典的な核生成・成長モデルは, 低温相のドメイ ンの成長とともに半值幅が減少し, 各成長曲線をインキ ユベーション・タイムで時間をスケールすると一つのユ ニヴァーサル曲線になることが期待される. しかし， $T_{\mathrm{p}}$ 以上の低温相の半值幅の時間変化はほば一定で, その上, 図 14 のように時間をインキュベーション・タイムでス ケールしても, 成長曲線は一つのユニヴァーサル曲線に ならない.したがって,このことからも，T>T徂でドメ イン壁の移動で記述される古典的な理論とは異なる成長 が実現してると思われる．結局，仮定 $1 ， 2$ の両方を用い て一連の実験結果を説明することができる．また，仮定 1 だけをふまえた二次元的な理想化された核生成・成長モ デルが提案されている.48)

図14 インキュベーション・タイムで時間をスケールした 各温度の成長曲線.

\section{6. おわりに}

In-Tl 合金で相転移前駆現象の多くの報告がなされた が, もしかしたら $T_{\mathrm{p}}$ 以上の通常と異なる成長過程を観察 していたのかもしれない.つまり，相転移が起きないと 考えられていた温度領域で時間を待てば相転移が起こっ てしまうことが明らかになったからである。すると，今 後，時間軸を考慮した転移点の再定義が必要で，今まで の転移点 $M_{\mathrm{s}}$ よりも $T_{0}$ の方が適切だと思われる．なぜな らば $T_{0}$ 以上の温度範囲では熱力学的（マクロ）に相転移 が起こらないからである。また, 結晶学において構造解 析は物理・化学・生物・鉱物の各分野にわたる共通言語 であるように，カイネティクスも将来このような役割を 果たすだろうと思われる.

\section{謝 辞}

最後に，本研究を行うにあたり，筑波大を退官なされ た星埜禎男教授，鈴木哲郎教授，奈良女子大の松尾欣枝 教授, 阪大工学部の掛下知行助教授, 東大物性研の加倉 井和久助教授，今井正幸助手に御指導，有益な助言をし ていただき感謝します。

\section{文献}

1) A. N. Kolmogorov: Bull. Acad. Sci. U.S.S.R., Phys. Ser. 3, 555 (1937) .

2) W. A. Johnson and R. F. Mehl: Trans. AIME 135, 416 (1939).

3) M. Avrami: J. Chem. Phys. 9, 177 (1941).

4) J. W. Cahn: Acta Metall. 4, 449 (1956).

5) J. W. Cahn and J. E. Hilliard: J. Chem. Phys. 31, 688 (1959).

6) H. Furukawa: Adv. Phys. 34, 703 (1985).

7）川崎恭治：日本物理学会誌 38, 919 (1983).

8）好村滋洋：固体物理 19,711 (1984).

9) 山田安定：固体物理 20,151 (1985).

10）太田隆夫：物理学最前線 10, “界面の不安定性とパターン形成”, 共立出版 (1985). 
11）宮崎 亨, 小山敏幸：日本金属学会会報 34, 434（1995）

12) T. Suzuki: Metall. Trans. A 12A, 709 (1981).

13) R. B. Griffiths: Phys. Rev. Lett. 14, 623 (1965).

14) K. G. Wilson: Phys. Rev. B4, 3174 (1971).

15) 高安秀樹：“フラクタル科学”, 朝倉書店 (1987).

16） H. ハーケン著, 牧島邦夫, 小森尚志訳：“共同現象の数理”, 東海大学出版会 (1980).

17) Y. Yamada: Ferroelectrics 35, 51 (1981).

18) S. Komori, S. Hayase and H. Terauchi: J. Phys. Condens. Matter 1, 3789 (1989).

19) Y. Noda, S. Nishihara and Y. Yamada: J. Phys. Soc. Jpn. 53, 4241 (1984).

20) R. F. Shannon Jr, S. E. Nagler, C. R. Harkless and R. M. Nicklow: Phys. Rev. B46, 40 (1992).

21) N. Hamaya, Y. Yamada, J. D. Axe, D. P. Belanger and S. M. Shapiro: Phys. Rev. B33, 7770 (1986).

22) J. D. Axe and Y. Yamada: Phys. Rev. B34, 1599 (1986).

23）森井幸生, 片野進：日本結晶学会誌 36, 107 (1994).

24) 古坂道弘, 藤川辰一郎：日本結晶学会誌 36, 113 (1994).

25) H. Iwasaki, Y. Matsuo, K. Ohshima and S. Hashimoto: J. Appl. Cryst. 23, 509 (1990).

26）掛下知行, 山岸昭雄, 遠藤将一：日本金属学会会報 32, 591 (1993).

27) T. Kakeshita, K. Kuroiwa, K. Shimizu, T. Ikeda, A. Yamagishi and M. Date: Mater. Trans. JIM 34, 415 (1993).

28) T. Kakeshita, T. Saburi and K. Shimizu: ICOMAT-'95 (1995) in press.

29) T. Kakeshita, K. Shiba, T. Fukuda, T. Saburi and S. Endo: Mater. Trans. JIM 37, to be published.

30) T. Kakeshita, T. Fukuda and T. Saburi: Scripta Metall. 34, 147 (1996).

31) T. Kakeshita, T. Takeguchi, T. Fukuda and T. Saburi: Mater. Trans. JIM 37, 299 (1996)

32) T. Kakeshita, K. Kuroiwa, K. Shimizu, T. Ikeda, A. Yamagishi and M. Date: Mater. Trans. JIM 34, 423 (1993).

33) K. Oguchi, K. Tajima and Y. Shinoda: J. Phys. Soc. Jpn. 60, 2371 (1991).

34) K. Tajima, Y. Shinoda and M. Tadakuma: J. Magn. Magn. Mater. 140-144, 765 (1992).

35) M. Tadakuma, K. Tajima and G. Masada: J. Phys. Soc. Jpn. 64, 2074 (1995).

36) M. Imai, K. Mori, T. Mizukami, K. Kaji and T. Kanaya: Polymer
33, 4457 (1992).

37) M. Imai: K. Kaji and T. Kanaya: Phys. Rev. Lett. 71, 4162 (1993).

38）今井正幸, 梶 慶輔: 表面 32, 436 (1994).

39) R. Berliner, O. Fajen, H. G. Smith and R. L. Hitterman: Phys. Rev. B40, 12086 (1989).

40) G. Ernst, C. Artner, O. Blaschko and G. Krexner: Phys. Rev. B33, 6465 (1986).

41) O. Blaschko and G. Krexner: Phys. Rev. B30, 1667 (1984).

42) H. G. Smith: Phys. Rev. Lett. 58, 1228 (1987).

43) H. Abe, K. Ohshima, T. Suzuki, S. Hoshino and K. Kakurai: Phys. Rev. B49, 3739 (1994).

44) P. H. Dederichs: J. Phys. F 3, 471 (1973).

45) T. R. Finlayson and H. G. Smith: Metall. Trans. A 19A, 193 (1988).

46) H. Abe, M. Ishibashi, K. Ohshima, T. Suzuki, M. Wuttig and K. Kakurai: Phys. Rev. B50, 9020 (1994).

47) A. L. Roitburd: Mater. Sci. Eng. A127, 229 (1990).

48) H. Abe, K. Ohshima and T. suzuki: Mater. Trans. JIM 36, 1200 (1995).

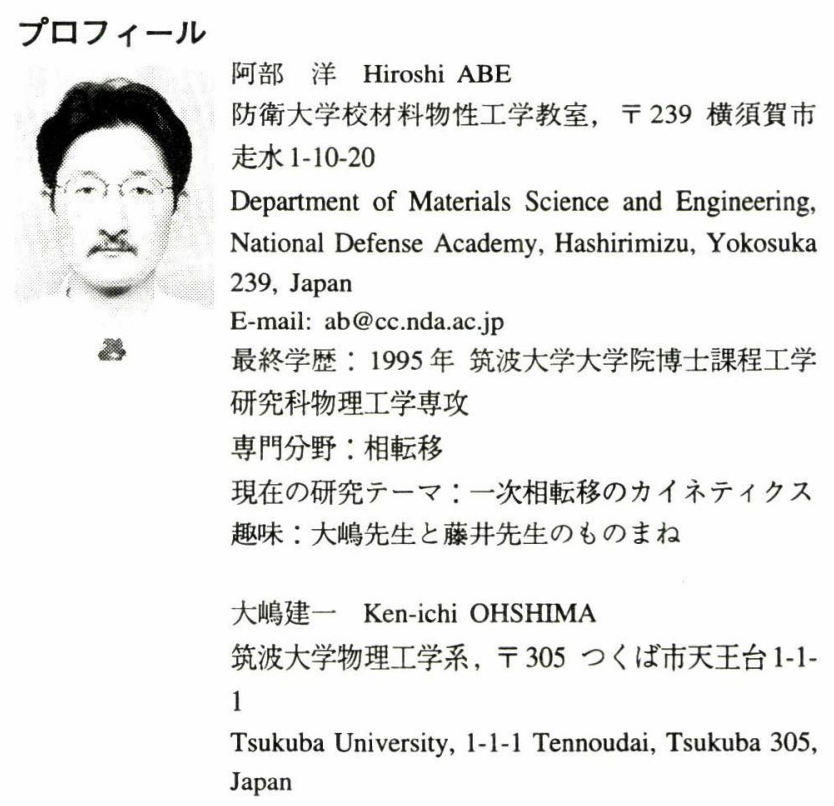

